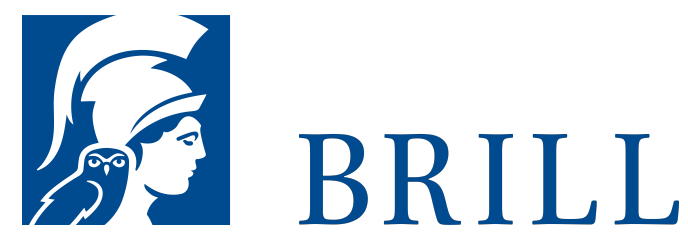

\title{
Sinn und Gedächtnis
}

Die Zeitlichkeit des Sinns und die Figuren ihrer Reflexion

Author: Thomas Khurana

Sinn ist gedächtnishaft, und Gedächtnis ist nur von der zeitlichen Tiefenstruktur des Sinns aus zu verstehen - das ist die doppelte These dieses Buches. Im ersten Teil beschreibt Thomas Khurana - unter Stichworten wie Ereignis, Wiederholung und Anachronie - die grundlegende Zeitlichkeit sinnhafter Vollzüge. In einem zweiten Teil charakterisiert er Formen des expliziten Gedächtnisses - wie Datum, Bild, Phantom - als Reflexionsfiguren dieser Zeitlichkeit. An dem komplexen und prekären Bezug auf das Vergangensein des Vergangenen werden Aporien aufgewiesen, die nicht nur die Struktur des Gedächtnisses ausmachen, sondern die innere Unruhe und Offenheit des Sinns selbst begründen. Im Anschluss an Luhmann, Derrida und Wittgenstein macht Khurana so den grundlegenden Charakter von Gedächtnis deutlich, der jene Zeitlichkeit fundiert, die in der jüngeren Sprachphilosophie so auffällig ignoriert wird und die doch konstitutiv ist für die Form sinnhafter Praktiken.

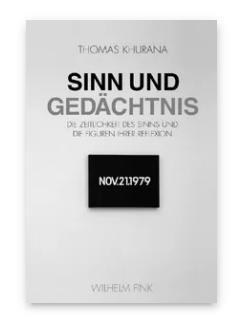

Pages: 304

Seiten

Language:

German

Subjects:

General,

Philosophy

Publisher: Brill |

Fink

E-Book (PDF)

Released online:

20 Jan 2020

ISBN: 978-3-

8467-4519-9

List price

USD \$63.00

Paperback

Publication date:

O5 Oct 2007

ISBN: $978-3^{-}$

7705-4519-3

List price

USD $\$ 63.00$ 
For more information see brill.com

Order information: Order online at brill.com +44330 333 0049 | customerservices@brill.com Submission information: brill.com/authors

Titles published by Brill | Fink, Brill | mentis or Brill | Schöningh: +49(o)715413279216| brill@brocom.de 